\title{
Rheumatoid rosette in juvenile rheumatoid arthritis
}

\author{
A. M. PRIEUR, J. F. BACH, C. GRISCELLI, C. JUDET, J. J. BALLET, C. BACH, and \\ P. MOZZICONACCI \\ From Unité Immunopathologie, Clinique Médicale Infantile, and Clinique Néphrologique, Hôpital Necker- \\ Enfants Malades, Paris \\ Prieur, A. M., Bach, J. F., Griscelli, C., Judet, C., Ballet, J. J., Bach, C., and \\ Mozziconacci, P. (1974). Archives of Disease in Childhood, 49, 438. Rheumatoid \\ rosette in juvenile rheumatoid arthritis. The rheumatoid rosette test was \\ performed in 159 children. Positive results were found more frequently in juvenile \\ rheumatoid arthritis when more than four joints were involved. It is not to be \\ considered as a diagnostic test since 'false positive' tests occur in other diseases. The \\ immunological significance of the rosette test is discussed.
}

Rheumatoid rosettes (RR) are defined by the adherence of immunoglobulin-coated red cells around lymphocytes. The RR phenomenon might be the expression of rheumatoid factor produced at the cellular level. Though its immunological significance is not well established, it perhaps reflects the hyperstimulation of a bone-marrow dependent system, the B lymphocytes.

$R R$ have been found in adults with seronegative as well as seropositive rheumatoid arthritis (Bach, Delrieu, and Delbarre, 1970), and it might be expected that the RR phenomenon would be found in juvenile rheumatoid arthritis (JRA), since those patients are known to be seronegative in most cases (Laaksonen, 1966; Calabro and Marchesano, 1967). Therefore, the RR test was performed on 63 children with JRA and on 96 controls.

\section{Material and methods}

Material (Table I).

$J R A$ (63 cases). Three groups of patients were considered according to the presence of systemic symptoms, number of joint manifestations, and laboratory findings (Calabro and Marchesano, 1967; Bywaters, 1967).

(a) Patients with systemic disease (group I, 32 cases). Generally the initial symptoms included high fever, symmetric arthritis, rash, splenomegaly and/or adenopathy, and serositis. High sedimentation rates and leucocytosis were observed in all children. Onset of the disease usually occurred before the age of 7 . The evolution was polycyclic with recurrent systemic symptoms in 21 children and joint destruction in 9

Received 1 November 1973.

\section{TABLE I}

Rheumatoid rosette $(R R)$ test in 63 children with juvenile rheumatoid arthritis (JRA) and in 96 controls

\begin{tabular}{|c|c|c|}
\hline & \multicolumn{2}{|c|}{ Rheumatoid rosette levels } \\
\hline & $\geqslant 6 / 1000$ cells & $<6 / 1000$ cells \\
\hline $\begin{array}{l}\text { JRA (63 cases) } \\
\text { Group I (32) } \\
\text { Group II (14) } \\
\text { Group III (17) } \\
\text { Rheumatological diseases (17 } \\
\text { cases) } \\
\text { Rheumatic fever (8) } \\
\text { Arthralgia (9) } \\
\text { Immunological diseases (14 } \\
\text { cases) } \\
\text { Deficiency (8) } \\
\text { Hyperimmune diseases (6) } \\
\text { Infectious diseases (22 cases) } \\
\text { Bacterial infections (10) } \\
\text { Viral infections (12) } \\
\text { Normal controls (43 cases) }\end{array}$ & $\begin{array}{l}1 \\
2 \\
2 \\
1 \\
1\end{array}$ & $\begin{array}{r}7 \\
4 \\
8 \\
11 \\
42\end{array}$ \\
\hline
\end{tabular}

children. In 2 children remission had occurred more than 6 months before testing.

(b) Patients with polyarticular disease (group II, 14 cases). Symptoms were articular without rash or hypertrophy of lymphoid organs. Fever was moderate and sedimentation rates were only slightly increased. The onset of disease occurred after the age of 7 and joint deterioration was progressive with ankylosis. These patients resemble the adult cases.

(c) Patients with mono- or oligoarticular disease (group III, 17 cases). No systemic symptom was present and less than 4 joints were involved. Sedimentation rate was normal.

Controls (96 children). 43 were normal children, aged 2 to 15 years. 22 were patients with acute infectious 
diseases, 10 of whom had bacterial infections (septicaemia 4, abcess 3, urinary tract infection 1, pulmonary infections 2 ) and 12 had viral infections (infectious mononucleosis 5 , viral hepatitis 7 ).

17 patients included 8 cases of rheumatic fever and 9 cases of transitory arthralgia of unknown origin.

14 patients had diseases involving the immune system. 8 had an immune deficiency (according to the classification of the World Health Organization) (Fudenberg et al., 1971); 4 had ataxia telangiectasia, 2 had Wiskott-Aldrich syndrome, 1 had selective IgM deficiency, 1 had global hypo- $\gamma$-globulinaemia. 6 had hyperimmune diseases (systemic lupus erythematosus 2 , periarteritis nodosa 1 , Behçet's syndrome 1 , serum sickness 1 , dermatomyositis 1 ).

Methods. The RR test was performed according to the original technique (Bach and Delbarre, 1968) with two modifications, dealing with lymphocyte isolation and erythrocyte sensitization.

Cellular isolation was accomplished using a FicollHypaque gradient (Harris and Ukaejiofo, 1969). This technique does not decrease monocyte concentrations as does the nylon infiltration used in the original $R R$ technique. It was verified that the monocyte contamination was lower than $5 \%$ using our own Ficoll technique. Erythrocyte sensitization with rabbit immunoglobulin was performed using a pool of antihuman haemagglutinin (Pasteur Institute, Paris). Such haemagglutinin was used under the agglutinating concentration.

The presence of a visible lymphocyte with adherence of more than four erythrocytes was considered necessary for identification of a rosette (Fig. 1).

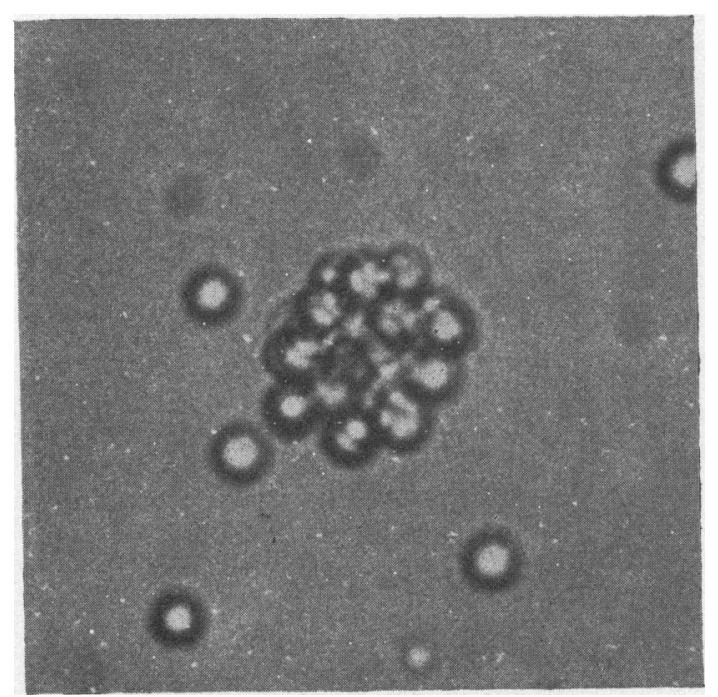

FIG. 1.-Rheumatoid rosette observed after adherence of sensitized erythrocytes around a lymphocyte.

\section{Results}

The results (Table II, Fig. 2) show that RR were found with a significant frequency $(\geqslant 6 / 1000$ cells) in 28 out of 63 children with JRA.

\section{TABLE II}

Rheumatoid rosette levels compared to the evolutive mode in JRA with a systemic onset

\begin{tabular}{l|c|c}
\hline & \multicolumn{2}{|c}{ Rheumatoid rosette levels } \\
\cline { 2 - 3 } & $\geqslant 6 / 1000$ cells & $<6 / 1000$ cells \\
\hline Polycyclic course (21 cases) & 11 & 10 \\
Continuous course (9 cases) & 5 & .4 \\
Remission (2 cases) & 0 & 2 \\
\hline
\end{tabular}

JRA. Children with systemic symptoms (group I) and those with progressive polyarticular disease (group II) were more often positive $(50 \%$ and $71 \%$ ) than those children with mono- or oligoarticular diseases (group III) (12\%). This difference is highly significant $(P \bumpeq 0.001)$ using the $\chi^{2}$ test. Conversely, the difference between group I and II was not significant $(P \bumpeq 0 \cdot 2)$.

In group I the incidence of positive $R R$ tests was the same in children with recurrent systemic symptoms and in those with continuous and progressive joint involvement (Table II). In 2 children the test was negative during a long remission of 6 months.

In all groups no correlation was found between positivity and the various clinical and laboratory data (fever, lymphoid hypertrophy, sedimentation rate, leucocytosis, immunoglobulin concentrations) at the time of the test. The RR test was positive only 3 times among the 6 patients with detectable serum rheumatoid factor.

Control subjects. Among the 17 rheumatological controls, positive tests were observed in only 2 cases with rheumatic fever.

In immunological diseases the test was positive in 1 patient with an illness in the acute phase (9 days), in the patient with Behçet's syndrome, and in a child with selective IgM deficiency.

Three positive tests were observed in the group of 22 children with acute infections (1 case of infectious mononucleosis with liver lesion and urticaria, 1 case of abcess, and 1 case of bronchiectasis).

Only 1 case was positive among the 43 normal controls.

\section{Discussion}

Frequency. In adult rheumatoid arthritis, the RR level was found to be significantly higher in 


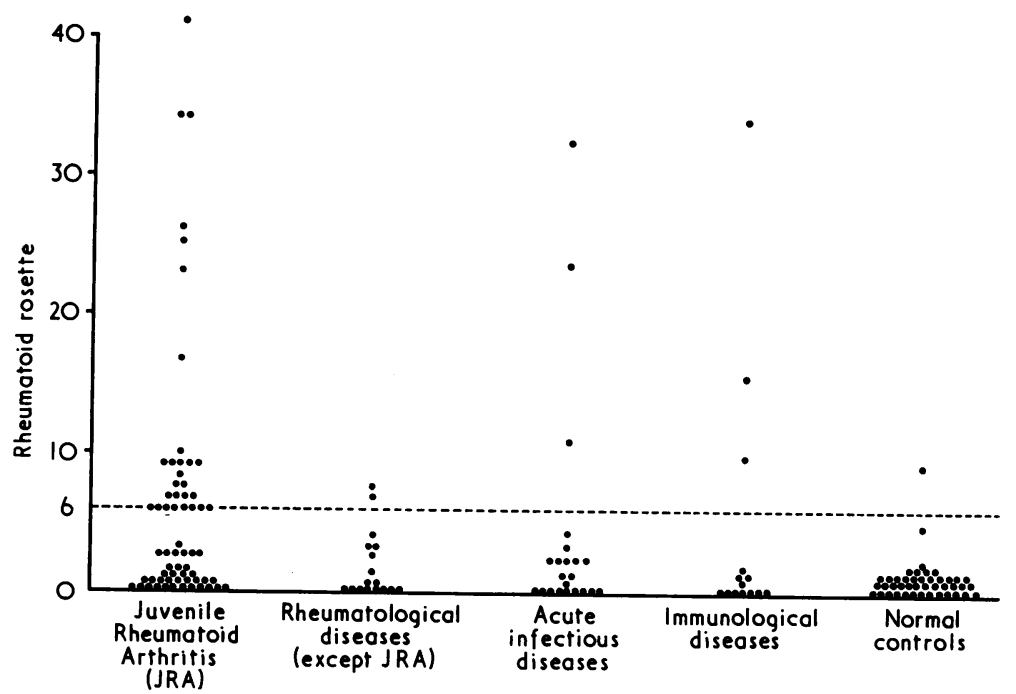

FIG. 2.-Rheumatoid rosette levels per 1000 cells in juvenile rheumatoid arthritis and in controls.

seropositive and in seronegative diseases than in controls, except in liver diseases or gout (Bach et al., 1970). In JRA, being often seronegative, we have found $R R$ levels of the same order as that shown in adults.

Biological significance. The biological significance of the rheumatoid rosette (RR) phenomenon is still a matter of speculation.

The first possibility which has to be discussed is rosette formation by monocytes. In fact, it is known that macrophages and monocytes have receptors for the $\mathrm{Fc}$ portion of immunoglobulins ( $\mathrm{Ig}$ ) and Ig-coated erythrocytes do bind to monocytes, as shown by Lobuglio, Cotran, and Jandl (1967). Electromicroscopy and light microscopy studies have shown that in the precise technical conditions used in our test monocytes form rosettes, and this is why in the routine $R R$ technique monocytes are eliminated from the preparation by filtration on a nylon column or incubation in a plastic tube for 90 minutes. In the case of this particular study, though these procedures have not been used regularly, it has been verified that monocytes did not interfere to a large extent in rosette formation. Finally, the problem is to discuss the significance of the RR-forming lymphocytes.

Two main possibilities must be discussed. The first refers to nonspecific binding of immune complexes on the surface of lymphocytes, probably bone-marrow dependent cell line (B lymphocytes) through receptors for Fc (Bianco, Patrick, and
Nussenzweig, 1970). A technique similar to our own, using human antibody, has been described for the detection of $B$ cells and it is probable that the receptor in question is related to the receptor for aggregated Ig. The second possibility refers to specific rheumatoid-like anti-Ig receptor. The question then being whether the cells bearing these receptors are $B$ or $T$ cells (thymus-dependent cell $\bar{\partial}$ line).

It is difficult to establish clear differences in the present state of knowledge, between receptors for Fc and rheumatoid-like receptors. However, one may note that in our technique we use 7S Ig to sensitize the erythrocytes, and that receptors for antibodycoated red cells mainly bind 19S Ig (Ross et al., 1973). Moreover, it has been shown by Brain and Gordon (1971) that ALS did not inhibit B cells with receptors for $F c$, whereas ALS does inhibit RR formation at very low concentrations, of the order of $1 / 50,000$. Lastly, RR are found under all conditions where rheumatoid factor is found, for $N$ example in liver diseases or gout, in all situations in which increase in B cell number has not been reported (Bach et al., 1970).

This phenomenon must be discussed while considering the biological disturbances known in 0 rheumatoid arthritis, especially in JRA, the clinical $\overparen{D}$ findings and course of the disease, and the practical interest of the test.

It would be of interest to attempt to place the $R R$ phenomenon among the relative number of $B$ and $T$ cells in JRA. Until now, to our knowledge, this study has been done only in adult rheumatoid 
arthritis (Papamichail, Brown, and Holborow, 1971; Mellbye et al., 1972). The results are quite diverse, but it appears that $\mathrm{T}$ cells are decreased in patients with more severe disease (Froland, Natvig, and Husby, 1973; Williams et al., 1973). A preliminary study in our group on 17 patients seems to confirm this result in JRA: the percentage of $T$ cells forming spontaneous sheep red blood cell rosettes (Jondal, Holm, and Wigzell, 1972; Bach, 1974) was lower (mean 53\%, range 12-73\%) than in normal children (mean $67 \%$, range $53-75 \%$ ) (A. M. Prieur and C. Griscelli, in preparation). This decrease of $T$ cells might be the consequence of a relative increase of $B$ cells, to which RR might belong.

In fact, numerous humoral data are consistent with the enormous immunological activity of the B system in juvenile disease. High levels of immunoglobulin are found more frequently to be caused by an increase of IgG class than IgA or IgM (Cassidy and Valkenburg, 1967; Houba and Bardfeld, 1969), or IgD (Geny, Griscelli, and Mozziconacci, 1974), and if rheumatoid factors cannot be found in more than $30 \%$ of children when aggregative tests detecting IgM anti-immunoglobulin are performed (Laaksonen, 1966; Calabro and Marchesano, 1967; Hanson, Drexler and Kornreich, 1969), they are present in the serum of cases with active JRA in IgG or IgA class using other techniques (Torrigiani $e t$ al., 1969; Peltier, Atra, and Haim, 1971). In addition to rheumatoid factor activity, other antibody activities can be observed, such as the presence of IgG antinuclear antibodies (Petty et al., 1969; Munthe, 1972) and antibodies against streptococcus, viruses (rubella, measles), and mycoplasma antigens (unpublished data).

This antibody activity may have an aetiological significance, but it seems to be the reflection of a nonspecific hyperimmune activity as it has been shown in other diseases (Evans and Rothfield, 1973). The increase of $R R$ level is probably one aspect of the hyperactivity of the $B$ cell line.

Relations to clinical pattern. In our study it is noteworthy that only children with polyarticular involvement showed a significant incidence of positive $R R$ test and it is only in such patients that long-term chronic arthritis generally occurs, in contrast with patients with oligoarticular lesions. No correlation could be found between a positive $R R$ test and particular clinical symptoms at the time of the test or with the duration of the disease. In addition, steroid therapy did not significantly modify the test in our series. On the other hand, the $R R$ test was negative in children in remission.
Practical value of the test. A few control patients, especially those with acute bacterial or viral infection, showed a positive result which impairs the clinical validity of the technique in individual cases. However, this is a general comment also true for evaluation of serum rheumatoid factor, since a significant incidence of rheumatoid factor is also found in nonrheumatic diseases such as infections and liver diseases, especially when using the more sensitive serological techniques (Grieble et al., 1969).

Statistically, the RR test is more often positive in JRA when more than four joints are involved; nevertheless, it cannot be considered by itself as a diagnostic test for an individual case.

This work was done with the help of I.N.S.E.R.M. Commission 13.

\section{REFERENCES}

Bach, J. F. (1974). Evaluation of $T$ cells and thymic serum factors in man using the rosette technique. Transplantation Reviews, 16, 1974.

Bach, J. F., and Delbarre, F. (1968). Nouvelle métode de détection du facteur rhumatoïde au niveau cellulaire. Comptes Rendus de l'Académie des Sciences de Paris, 267, 134.

Bach, J. F., Delrieu, F., and Delbarre, F. (1970). Rheumatoid rosette. A diagnostic test unifying seropositive and seronegative rheumatoid arthritis. American fournal of Medicine, 49, 213.

Bianco, C., Patrick, R., and Nussenzweig, V. (1970). A population of lymphocytes bearing a membrane receptor for antigenantibody-complement complexes. I. Separation and characterization. Fournal of Experimental Medicine, 132, 702.

Brain, P., and Gordon, J. (1971). Rosette formation by peripheral lymphocytes. II. Inhibition of the phenomenon. Clinical and Experimental Immunology, 8, 441.

Bywaters, E. G. L. (1967). Categorization of medicine: a survey of Still's disease. Annals of the Rheumatic Diseases, 26, 185.

Calabro, J. J., and Marchesano, J. M. (1967). Juvenile rheumatoid arthritis. New England fournal of Medicine, 277, 696.

Cassidy, J. T., and Valkenburg, H. A. (1967). A five year prospective study of rheumatoid factor tests in juvenile rheumatoid arthritis. Arthritis and Rheumatism, 10, 83.

Evans, A. S., and Rothfield, N. F. (1973). E. B. virus and other viral antibodies in systemic lupus erythematosus. Lancet, 1, 1127.

Froland, S. S., Natvig, J. B., and Husby, G. (1973). Immunological characterization of lymphocytes in synovial fluid from patients with rheumatoid arthritis. Scandinavian fournal of Immuno$\log y, 2,67$.

Fudenberg, H., Good, R. A., Goodman, H. C., Hitzig, W., Kunkel, H. G., Roitt, I. M., Rosen, F. S., Rowe, D. S., Seligmann, M., and Soothill, J. H. (1971). Primary immunodeficiencies. Report of a World Health Organization committee. Pediatrics, 47, 927.

Geny, B., Griscelli, C., and Mozziconacci, P. (1974). Serum IgD levels in juvenile rheumatoid arthritis. Biomedicine. (In the press.)

Grieble, H. G., Bach, G. L., Szanto, M., and Anderson, T. O. (1969). The serologic diagnosis of rheumatoid arthritis. Fournal of Chronic Diseases, 21, 667.

Hanson, V., Drexler, E., and Kornreich, H. (1969). The relationship of rheumatoid factor to age of onset in juvenile rheumatoid arthritis. Arthritis and Rheumatism, 12, 82.

Harris, R., and Ukaejiofo, E. O. (1969). Rapid preparation of lymphocytes for tissue-typing. Lancet, 2, 327.

Houba, V., and Bardfeld, R. (1969). Serum immunoglobulins in juvenile rheumatoid arthritis. Annals of the Rheumatic Diseases, 28, 55. 
Jondal, M., Holm, G., and Wigzell, H. (1972). Surface markers on human $T$ and $B$ lymphocytes. I. A large population of lymphocytes forming nonimmune rosettes with sheep red blood cells. Fournal of Experimental Medicine, 136, 207.

Laaksonen, A. (1966). A prognostic study of juvenile rheumatoid arthritis. Acta Paediatrica Scandinavica, 55, Suppl. 166.

Lobuglio, A. F., Cotran, R. S., and Jandl, J. H. (1967). Red cells coated with immunoglobulin G: binding and sphering by mononuclear cells in man. Science, 158, 1582.

Mellbye, O. J., Messner, R. P., Debord, J. R., and Williams, R. C. (1972). Immunoglobulin and receptors for C3 or lymphocytes from patients with rheumatoid arthritis. Arthritis and Rheumatism, 15, 371.

Munthe, E. (1972). Anti IgG and antinuclear antibodies in juvenile rheumatoid arthritis. Scandinavian fournal of Rheumatology, 1, 161.

Papamichail, M., Brown, J. C., and Holborow, E. J. (1971). Immunoglobulins on the surface of human lymphocytes. Lancet, 2, 850 .

Peltier, A. P., Atra, E., and Haim, T. (1971). Detection of serum rheumatoid factors by immunofluorescence (IF). Arthritis and Rheumatism, 14, 179.
Petty, R. E., Storm, P. B., Cassidy, J. T., Burt, A., and Sullivan, D. B. (1969). Immunologic correlates of antinuclear antibody in juvenile rheumatoid arthritis. Arthritis and Rheumatism, 12, 323.

Ross, G. D., Rabellino, E. M., Polley, M. J., and Grey, H. M. (1973). Combined studies of complement receptor and surface immunoglobulin-bearing cells and sheep erythrocytes rosette-forming cells in normal and leukemic human lymphocytes. Fournal of Clinical Investigation, 52, 377.

Torrigiani, G., Ansell, B. M., Chown, E. E. A., and Roitt, I. M. (1969). Raised IgG antiglobulin factors in Still's disease. Annals of the Rheumatic Diseases, 28, 424.

Williams, R. C., DeBord, J. R., Mellbye, O. J., Messner, R. P., and Lindström, F. D. (1973). Studies of T-and B-lymphocytes in patients with connective tissue diseases. Fournal of Clinical Investigation, 52, 283.

Correspondence to Dr. C. Griscelli, Unité Immunopathologie, Clinique Médicale Infantile, Hôpital NeckerEnfants Malades, 149 Rue de Sèvres, Paris 15e. 